

\section{DISCLAIMER}

This book was prepared as an account of work sponsored by an agency of the United States Government. Neither the United States Government nor any agency thereof, nor any of their employees, makes any warranty, express or implied, or assumes any legal liability or responsibility for the accuracy, completeness, or usefulness of any information, apparatus, product or process disclosed, or represents that its use would not infringe privately owned rights. References herein to any specific commercial product, process, or service by trade name, trademark, manufacturer, or otherwise, does not necessarily constitute or imply its endorsement, recommendation, or favoring by the United States Government or any agency thereof. The views and opinions of authors expressed herein do not necessarily state or reflect those of the United States Government or any agency thereof. 


\title{
Removal of Cesium From a High-Level Calcined Waste by High Temperature Volatilization
}

\author{
J. A. Del Debbio
}

November 1994

Lockheed Idaho Technologies Company

PREPARED FOR THE

\author{
DEPARTMENT OF ENERGY \\ IDAHO OPERATIONS OFFICE \\ UNDER CONTRACT DE-ACO7-94ID13223
}




\section{DISCLAIMER}

Portions of this document may be illegible in electronic image products. Images are produced from the best available original document. 


\section{ACKNOWLEDGEMENTS}

The author wishes to acknowledge contributions made by several individuals. P. A. Tullock and L. O. Nelson produced the computer-generated schematics of the hot and cold test apparatus respectively. G. R. Gregston did the glass work on all the test equipment, contributed to its design and on many occasions repaired or reconstructed the equipment on short notice. L. E. Trejo developed the method for remote dissolution of actual calcine. The assistance and cooperation given by the staff and personnel at the Remote Analytical Laboratory (RAL) is greatly appreciated. J. M. Mines and I. R. Thomas provided consultation on the development of propagation of error formulas. The contributions made by R. D. Tillotson were particularly notable. He conducted the majority of the cold tests, made significant contributions to the design of the hot test apparatus and designed the tools for remote testing. He also assembled the remote test apparatus and conducted all the tests. These activities demanded a high skill level in manipulator operation, and considerable patience. 


\section{ABSTRACT}

Pyrochemical methods are being evaluated for the separation of actinides and fission products from inert material in high-level waste calcine. Separation processes have the potential of reducing waste disposal costs by reducing the volume of high-level waste requiring final disposal in a repository. Tests were conducted to evaluate high temperature volatilization for removing ${ }^{137} \mathrm{Cs}$ from four types of calcines. The results for pilot plant calcines indicate greater than $99 \%$ cesium removal for alumina and fluorinel/sodium calcines heated at $1000^{\circ} \mathrm{C}$ and $99 \%$ removal for zirconia calcine heated at $1100^{\circ} \mathrm{C}$. Tests with actual calcine generated at the New Waste Calcining Facility (NWCF) from a blend of aluminum, sodium and zirconium/fluorinel wastes resulted in $96 \%$ cesium removal at $1000^{\circ} \mathrm{C}$ and greater than $99 \%$ removal at $1170^{\circ} \mathrm{C}$. 


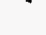




\section{SUMMARY}

Separation of actinides and fission products from inert materials in high-level waste (HLW) calcine has the potential of reducing $\mathrm{HLW}$ disposal costs by minimizing the volume of waste requiring final disposal in a repository. A pyrochemical process has been proposed in which calcine is heated at $1000^{\circ} \mathrm{C}$ to remove ${ }^{137} \mathrm{Cs}$ by volatilization. The calcine is then mixed with molten calcium chloride where actinide and inert metal oxides are reduced to metals with calcium. After separation of the metal component from the salt, inert metals (principally zirconium and aluminum) are separated as volatile chlorides in a chlorination step leaving actinide metals which are then incorporated into a final waste form. Tests were conducted to determine the feasibility of removing ${ }^{137} \mathrm{Cs}$ from calcine by heat treatment. The pilot plant calcines tested included Fluorinel/sodium (run LTWM-1-88), alumina (run 77) and zirconia (run 74). Experiments were also conducted at the Remote Analytical Laboratory (RAL) with actual calcine generated at the New Waste Calcination Facility (NWCF) from a blend of aluminum, zirconium/Fluorinel and sodium wastes. Volatilization of cadmium from the calcines was also determined. Other components of NWCF calcine whose volatilities were determined included $\mathrm{Hg},{ }^{90} \mathrm{Sr},{ }^{99} \mathrm{Tc}, \mathrm{Pu}$, and ${ }^{241} \mathrm{Am}$.

Fluorinel/sodium pilot plant calcine was heated for 5 hours at $600,700,900$, and $1000^{\circ} \mathrm{C}$ in separate experiments. Cesium volatilization at 900 , and $1000^{\circ} \mathrm{C}$ was $30 \%$, and $98 \%$ respectively. No measurable cesium volatilization occurred at 600 and $700^{\circ} \mathrm{C}$. All subsequent tests were conducted at 900 and $1000^{\circ} \mathrm{C}$ with 5 and 10 hour run times.

Cesium volatilization in 5 hours at $1000^{\circ} \mathrm{C}$ for alumina and Fluorinel/sodium calcine was $99 \%$ and $99.7 \%$ respectively. Cesium removal from zirconia calcine was $90 \%$ at $1000^{\circ} \mathrm{C}$ and $99 \%$ at $1100^{\circ} \mathrm{C}$. Cesium removal from NWCF calcine was $96 \%$ at $1000^{\circ} \mathrm{C}$ and $99.8 \%$ at $1170^{\circ} \mathrm{C}$. A 10 hour run at $1000^{\circ} \mathrm{C}$ resulted in $99 \%$ cesium volatilization from NWCF calcine. Lowering the temperature to $900^{\circ} \mathrm{C}$ and increasing run times to 10 hours resulted in large decreases in cesium removal except for Fluorinel/sodium calcine. The results for NWCF, Fluorinel/sodium, zirconia and alumina calcines were $59 \%, 94 \%, 41 \%$ and $11 \%$ respectively. Technetium- 99 removal from NWCF calcine was greater than $99 \%$ when heated at $1000^{\circ} \mathrm{C}$ for 5 hours. No ${ }^{99} \mathrm{Tc}$ was detected in the calcine after heating compared with $25 \mu \mathrm{g} / \mathrm{g}$ before heating. No volatilization of ${ }^{90} \mathrm{Sr}, \mathrm{Pu}$, or ${ }^{241} \mathrm{Am}$ was detected.

Mercury was removed from NWCF calcine to below detectable limits ( $>94 \%$ removal) after heating at both 900 and $1000^{\circ} \mathrm{C}$ for 5 hours. Mercury levels in the unheated calcine were 26 $\mu \mathrm{g} / \mathrm{g}$. Cadmium volatilization at $1000^{\circ} \mathrm{C}$ and 5 hours for NWCF, Fluorinel/sodium and zirconia calcines were $65 \% 69 \%$ and $54 \%$ respectively. Alumina calcine has only trace levels of cadmium.

Greater than $96 \%$ of the volatilized $\mathrm{Cs}, \mathrm{Cd}$ and ${ }^{99} \mathrm{Tc}$ condensed within $20-\mathrm{cm}$ of the heated zone indicating the absence of highly volatile species. Condensed volatiles dissolved readily in $3 \mathrm{~N}$ $\mathrm{HNO}_{3}$ allowing the recovery of a large percentage of volatilized components.

Recovery of volatilized Cs averaged $92 \%$ for all calcines tested. Recovery of ${ }^{99} \mathrm{Tc}$ from NWCF calcine was $83 \%$. Cadmium recovery was $89 \%$ for pilot plant calcines and $58 \%$ for NWCF calcine. 



\section{TABLE OF CONTENTS}

ACKNOWLEDGEMENTS $\ldots \ldots \ldots \ldots \ldots \ldots \ldots \ldots \ldots \ldots \ldots \ldots \ldots \ldots$ iii

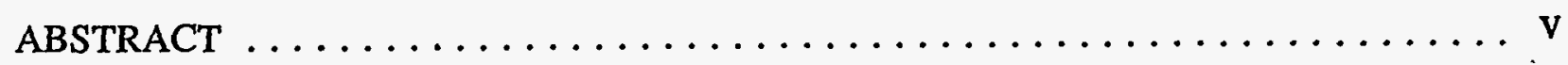

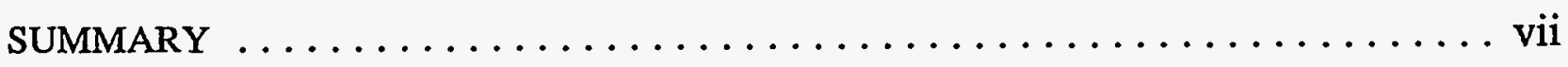

1. INTRODUCTION $\ldots \ldots \ldots \ldots \ldots \ldots \ldots \ldots \ldots \ldots \ldots \ldots \ldots \ldots \ldots \ldots \ldots \ldots$

2. CALCINE CHARACTERIZATION $\ldots \ldots \ldots \ldots \ldots \ldots \ldots \ldots \ldots \ldots \ldots$

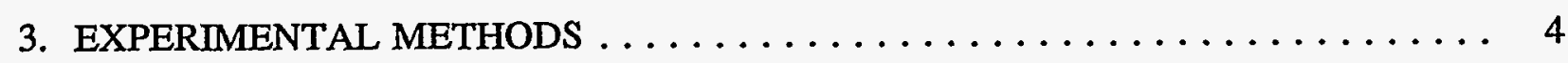

3.1 Cold Tests with Pilot Plant Calcines $\ldots \ldots \ldots \ldots \ldots \ldots \ldots \ldots \ldots, 4$

3.2 Hot Tests with NWCF Calcine $\ldots \ldots \ldots \ldots \ldots \ldots \ldots \ldots \ldots \ldots$

4. DATA ANALYSIS $\ldots \ldots \ldots \ldots \ldots \ldots \ldots \ldots \ldots \ldots \ldots \ldots \ldots \ldots \ldots \ldots \ldots$

5. RESULTS AND DISCUSSION $\ldots \ldots \ldots \ldots \ldots \ldots \ldots \ldots \ldots \ldots \ldots \ldots$

5.1 Volatilization of Semivolatile Components $\ldots \ldots \ldots \ldots \ldots \ldots \ldots \ldots$

5.2 Characterization of Condensed Semivolatiles $\ldots \ldots \ldots \ldots \ldots \ldots \ldots .12$

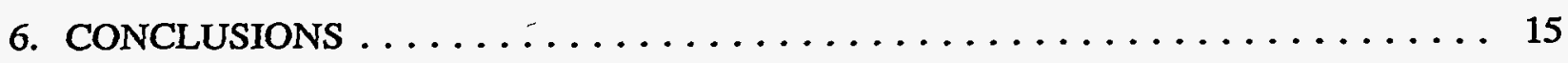

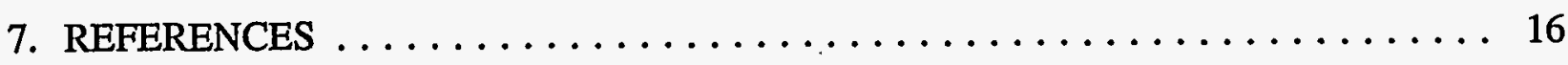

\section{TABLES}

Table I Elemental Analysis (Wt.\%) of Calcines Tested $\ldots \ldots \ldots \ldots \ldots \ldots \ldots \ldots, 2$

Table II X-Ray Diffraction Analysis of Calcines Used in the Calcine Volatiles Tests . . . 3

Table III Analysis of NWCF Calcine Sample Used in the Calcine Volatiles Tests . . . . 3

Table IV Effect of Temperature on Volatilization of Cesium and Cadmium from Fluorinel/Sodium Pilot Plant Calcine (Run LTWM-1-88) . . . . . . . 8

Table V Percent Volatilization of Semivolatile Components in Four Calcine Types . . . . 10

Table VI Percent Recovery of Volatilized Components .............. 12 
Table VII Elemental Analysis of Condensed Semivolatiles $\ldots \ldots \ldots \ldots \ldots \ldots \ldots$

Table VIII X-ray Diffraction Analysis of Condensed Semivolatiles $\ldots \ldots \ldots \ldots \ldots 14$

\section{FIGURES}

Figure 1. Cold Calcine Volatiles Test Apparatus for Pilot Plant Calcines ......... 4

Figure 2. Remote Hot Calcine Volatiles Test Apparatus for NWCF Calcine ....... 5

Figure 3. Percent Volatilization vs. Argon Purge Rate $\ldots \ldots \ldots \ldots \ldots \ldots \ldots$

Figure 4. Condensed Semivolatiles from Heating Alumina Calcine at $1000^{\circ} \mathrm{C}$

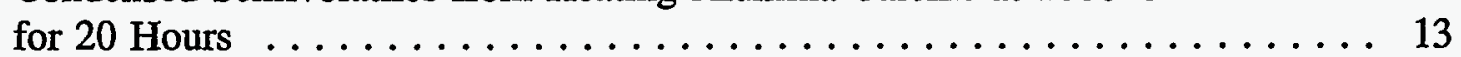

Figure 5. Condensed Semivolatiles from Heating Zirconia Calcine at $1000^{\circ} \mathrm{C}$

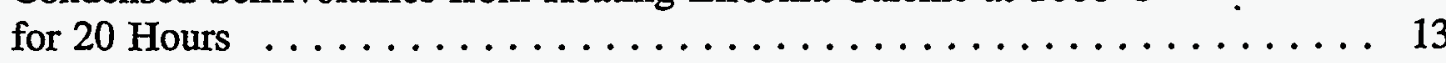




\section{INTRODUCTION}

A pyrochemical process is being considered for separating actinides and fission products from inerts in high-level waste calcine. The proposed process could minimize future disposal costs by reducing the volume of waste requiring final disposal in a repository. The first step in the process involves degassing the calcine by heating to $600^{\circ} \mathrm{C}$ followed by heat treatment at $1000^{\circ} \mathrm{C}$ or higher to volatilize ${ }^{137} \mathrm{Cs}$. The calcine is then treated with calcium in a molten salt to reduce actinide and inert metal oxides to metals. The resultant metal component is separated from the salt and chlorinated at $600^{\circ} \mathrm{C}$ to separate inert metals as volatile chlorides. Actinide chlorides are then reduced to metals with calcium and the metals incorporated into a final waste form. The volatilized ${ }^{137} \mathrm{Cs}$ may be condensed onto a matrix such as fiberglass, which is suitable for incorporation into a glass waste form. The condensed cesium may also be dissolved in water and the ${ }^{137} \mathrm{Cs}$ separated from condensed inerts using ion exchange methods.

Removal efficiencies of fission products (principally ${ }^{137} \mathrm{Cs}$ and ${ }^{90} \mathrm{Sr}$ ) and actinides must be maximized to allow disposal of the salt waste generated by the calcium reduction process as a low-level waste.

The volatility of cesium from glass, ceramics, and synthetic calcines has been described in the literature ${ }^{1,2,3}$ although volatilization mechanisms have not been identified. Sill ${ }^{4}$ has reported a cesium volatilization rate of $22.67 \pm 6.09 \% / \mathrm{hr}$ at $900^{\circ} \mathrm{C}$ when added as a tracer solution to a simulated granular basalt waste form. Extrapolation of this data to $1000^{\circ} \mathrm{C}$ indicates that $100 \%$ would volatilize in 1 hour. However, due to differences in waste form chemistry, cesium distribution and diffusion effects, cesium volatilization rates may be much lower for calcine.

This report describes experiments conducted to determine the effect of time and temperature on cesium volatilization from three pilot plant calcines and actual calcine generated at the NWCF. The pilot plant calcine types tested included zirconia (run 74), alumina (run 77), and Fluorinel/sodium (run LTWM-1-88). Zirconia and alumina calcine represent greater than $90 \%$ of the high-level waste calcine inventory. The NWCF calcine tested was generated from a blend of aluminum, zirconium/Fluorinel and sodium waste during campaign H3, phase 2 which ran from $3 / 93$ to $10 / 93$. Processing time of the three-way blend was approximately $40 \%$ of the total duration of the campaign. The type of waste processed, blend ratios, and feed rates change frequently during a campaign. The effects of these variables on cesium volatility is not known and was not an objective of this study. Other calcine components which may volatilize at high temperatures $\left(>900^{\circ} \mathrm{C}\right)$ and for which data is presented include cadmium, mercury, and ${ }^{99} \mathrm{Tc}$.

\section{CALCINE CHARACTERIZATION}

The elemental composition of the calcines tested is listed in Table I. The values for NWCF calcine are estimates calculated from feed compositions and blend ratios. The zirconia (run 74) and alumina (run 77) pilot plant calcines were generated in the $30-\mathrm{cm}$ calciner. The Fluorinel/sodium calcine (LTWM-1-88) was produced in the 10-cm calciner. The pilot plant calcine samples tested were taken from final bed material and were not stabilized (degassed). The NWCF calcine sample was taken during calciner operation after bed turnover had occurred. Table II lists the major chemical components as determined by X-ray diffraction analysis. With 
the exception of alumina calcine, the calcines tested are similar in chemical structure. The large amount of aluminum present in NWCF calcine may be present as amorphous $\mathrm{Al}_{2} \mathrm{O}_{3}$.

Table I

Elemental Analysis (Wt.\%) of Calcines Tested

\begin{tabular}{|c|c|c|c|c|}
\hline & $\begin{array}{c}\text { Zirconia } \\
\text { run } 74 \\
\end{array}$ & $\begin{array}{l}\text { Alumina } \\
\text { run } 77 \\
\end{array}$ & $\begin{array}{c}\text { Fluorinel/Sodium } \\
\text { LWTM-1-88 }\end{array}$ & $\mathrm{NWCF}^{\mathrm{a}}$ \\
\hline $\mathrm{Al}$ & 11.2 & 46.5 & 6.60 & 20.9 \\
\hline B & 1.10 & 0.20 & 1.10 & 0.96 \\
\hline $\mathrm{Ca}$ & 25.0 & 1.20 & 22.3 & 16.8 \\
\hline $\mathrm{Cd}$ & 0.09 & 0.01 & 4.90 & 1.28 \\
\hline $\mathrm{Cl}$ & $<0.20$ & $<0.20$ & 0.10 & 0.13 \\
\hline Cs & 0.38 & 0.47 & 0.36 & $\mathrm{~b}$ \\
\hline $\mathrm{Hg}$ & 0.10 & $<0.10$ & $<0.10$ & $26.0^{c}$ \\
\hline $\mathrm{F}$ & 17.4 & 0.80 & 13.0 & 11.4 \\
\hline $\mathrm{Fe}$ & 0.10 & 0.40 & 0.35 & 0.76 \\
\hline $\mathrm{K}$ & $<0.10$ & 0.40 & 0.35 & 0.76 \\
\hline $\mathrm{Na}$ & 0.40 & 1.80 & 3.41 & 2.96 \\
\hline $\mathrm{NO}_{3}^{-}$ & $<1.0$ & 1.60 & 11.3 & 6.02 \\
\hline $\mathrm{SO}_{4}=$ & 1.80 & 0.20 & 1.60 & 2.50 \\
\hline $\mathrm{Sr}$ & 0.78 & 0.50 & 0.59 & 0.13 \\
\hline $\mathrm{Zr}$ & 16.6 & 0.60 & 11.6 & 7.63 \\
\hline
\end{tabular}

a Estimates calculated from feed analyses, blend ratios, and other parameters. Cadmium, mercury and strontium values based on chemical analysis.

b Not determined.

c Units are $\mu \mathrm{g} / \mathrm{g}$. 
Table II

$\mathrm{X}$-Ray Diffraction Analysis of Calcines Used in the Calcine Volatiles Tests

\begin{tabular}{|c|c|c|c|}
\hline $\begin{array}{r}\text { Zirconia } \\
\text { run } 74\end{array}$ & $\begin{array}{l}\text { Alumina } \\
\text { run } 77\end{array}$ & $\begin{array}{l}\text { Fluorinel/Sodium } \\
\text { LWTM-1-88 }\end{array}$ & NWCF \\
\hline $\mathrm{CaF}_{2}$ & $\alpha-\mathrm{Al}_{2} \mathrm{O}_{3}$ & $\mathrm{CaF}_{2}$ & $\mathrm{CaF}_{2}$ \\
\hline $\mathrm{NaNO}_{3}$ & $\delta-\mathrm{Al}_{2} \mathrm{O}_{3}$ & $\mathrm{NaNO}_{3}$ & $\mathrm{NaNO}_{3}$ \\
\hline $\mathrm{ZrO}_{2}$ & $\mathrm{NaNO}_{3}$ & $\mathrm{ZrO}_{2}$ & $\mathrm{Ca}_{0.15} \mathrm{Zr}_{0.85} \mathrm{O}_{1.85}$ \\
\hline \multirow[t]{3}{*}{$\mathrm{Ca}_{0.15} \mathrm{Zr}_{0.85} \mathrm{O}_{1.85}$} & & $\mathrm{Ca}_{0.15} \mathrm{Zr}_{0.85} \mathrm{O}_{1.85}$ & Amorphous $\mathrm{Al}_{2} \mathrm{O}_{3}$ \\
\hline & & $\mathrm{CdO}$ & \\
\hline & & $\mathrm{CdS}$ & \\
\hline
\end{tabular}

Analysis of the NWCF calcine for major radionuclides and hazardous components is listed in Table III. The analyses were performed by dissolving the calcine in concentrated $\mathrm{HNO}_{3} / \mathrm{HCI}$ mixtures and analyzing the resultant solutions.

Table III

Analysis of NWCF Calcine Sample Used in the Calcine Volatiles Tests ${ }^{\mathrm{a}}$.

\begin{tabular}{|c|c|c|c|c|}
\hline Component & $\begin{array}{c}\text { Half-Life } \\
\mathrm{y}\end{array}$ & $\mu \mathrm{Ci} / \mathrm{g}$ & $\begin{array}{c}\text { Concentration } \\
\mu \mathrm{g} / \mathrm{g}\end{array}$ & wt.\% \\
\hline${ }^{137} \mathrm{Cs}$ & $3.0 \mathrm{E} 1$ & $2.4 \mathrm{E} 3$ & $2.8 \mathrm{E} 1$ & $2.8 \mathrm{E}-3$ \\
\hline${ }^{134} \mathrm{Cs}$ & $2.1 \mathrm{E} 0$ & $3.6 \mathrm{E} 1$ & $2.8 \mathrm{E}-2$ & 2.8 E-6 \\
\hline${ }^{154} \mathrm{Eu}$ & $8.6 \mathrm{E} 0$ & $4.0 \mathrm{E} 1$ & $1.5 \mathrm{E}-2$ & $2.8 \mathrm{E}-6$ \\
\hline${ }^{99} \mathrm{Tc}$ & $2.1 \mathrm{E} 5$ & $4.3 \mathrm{E}-1$ & $2.5 \mathrm{E} 1$ & $2.5 \mathrm{E}-3$ \\
\hline${ }^{90} \mathrm{Sr}$ & $2.9 \mathrm{E} 1$ & $3.7 \mathrm{E} 3$ & $2.7 \mathrm{E} 1$ & $2.7 \mathrm{E}-3$ \\
\hline${ }^{241} \mathrm{Am}$ & $4.3 \mathrm{E} 2$ & $1.3 \mathrm{E} 0$ & $3.9 \mathrm{E}-1$ & $3.9 \mathrm{E}-5$ \\
\hline Total U & NA & $\mathrm{b}$ & $<2.3 \mathrm{E} 2$ & $<2.3 \mathrm{E}-2$ \\
\hline Total $\mathrm{Pu}$ & NA & $1.7 \mathrm{E} 1$ & b & b \\
\hline $\mathrm{Cd}$ & NA & NA & $1.3 \mathrm{E} 4$ & $1.3 \mathrm{E} 0$ \\
\hline $\mathrm{Sr}$ & NA & $\mathrm{NA}$ & $1.3 \mathrm{E} 3$ & $1.3 \mathrm{E}-1$ \\
\hline
\end{tabular}

a Calcine sample taken on 6/10/93 (campaign H3) during processing of three-way blend of Aluminum (WM-182), Zirconium/Fluorinel (WM-187) and Sodium (WM-185) wastes. Blend ratio $=7 \mathrm{Al}: 4.2 \mathrm{Zr} / \mathrm{Fl}: 1.3 \mathrm{Na}$.

b Isotopic percentages needed to calculate these values were not determined.

NA $=$ Not applicable 


\section{EXPERIMENTAL METHODS}

\subsection{Cold Tests with Pilot Plant Calcines}

The test apparatus for the cold tests conducted with pilot plant calcines is illustrated in Figure 1. A weighed amount of calcine was added to a nickel weighing boat and placed inside the alumina tube. Sample weights were 21.2000 to 21.2800 grams. After purging the apparatus with argon for 15 minutes at ambient temperatures the calcine was heated at $300^{\circ} \mathrm{C}$ for approximately 1 hour to remove water. When condensed water vapor was no longer visible in the quartz tube outside the heated zone, the adapter and condenser were attached and the calcine was degassed at $600-700^{\circ} \mathrm{C}$ until no $\mathrm{NO}_{\mathrm{x}}$ vapors were visible (about $1 / 2$ hour). The calcine was then heated at the test temperature for either 5 or 10 hours. After cooling the apparatus under argon, the calcine was removed from the weighing boat and weighed. The heated calcine was sampled in a glove bag filled with argon to prevent sorption of water. Three samples of the calcine before and after heating were analyzed for cesium and cadmium to determine percent volatilization. Fluorinel/sodium calcine samples were dissolved by heating in concentrated $\mathrm{HNO}_{3} / \mathrm{HCl}$. Zirconia calcine before heat treatment dissolved in hot $\mathrm{HNO}_{3} / \mathrm{HCl}$, while samples heated to 900 and $1000^{\circ} \mathrm{C}$ required fusion with lithium tetraborate prior to dissolution in $\mathrm{HNO}_{3}$. Alumina calcine before and after heating also required lithium tetraborate fusion for dissolution. Cesium was analyzed by flame emission spectroscopy and cadmium by inductively coupled plasma (ICP) techniques. Volatiles which condensed downstream of the heated zone were dissolved in $3 \mathrm{~N}$ $\mathrm{HNO}_{3}$ and the solutions analyzed for cesium and cadmium.

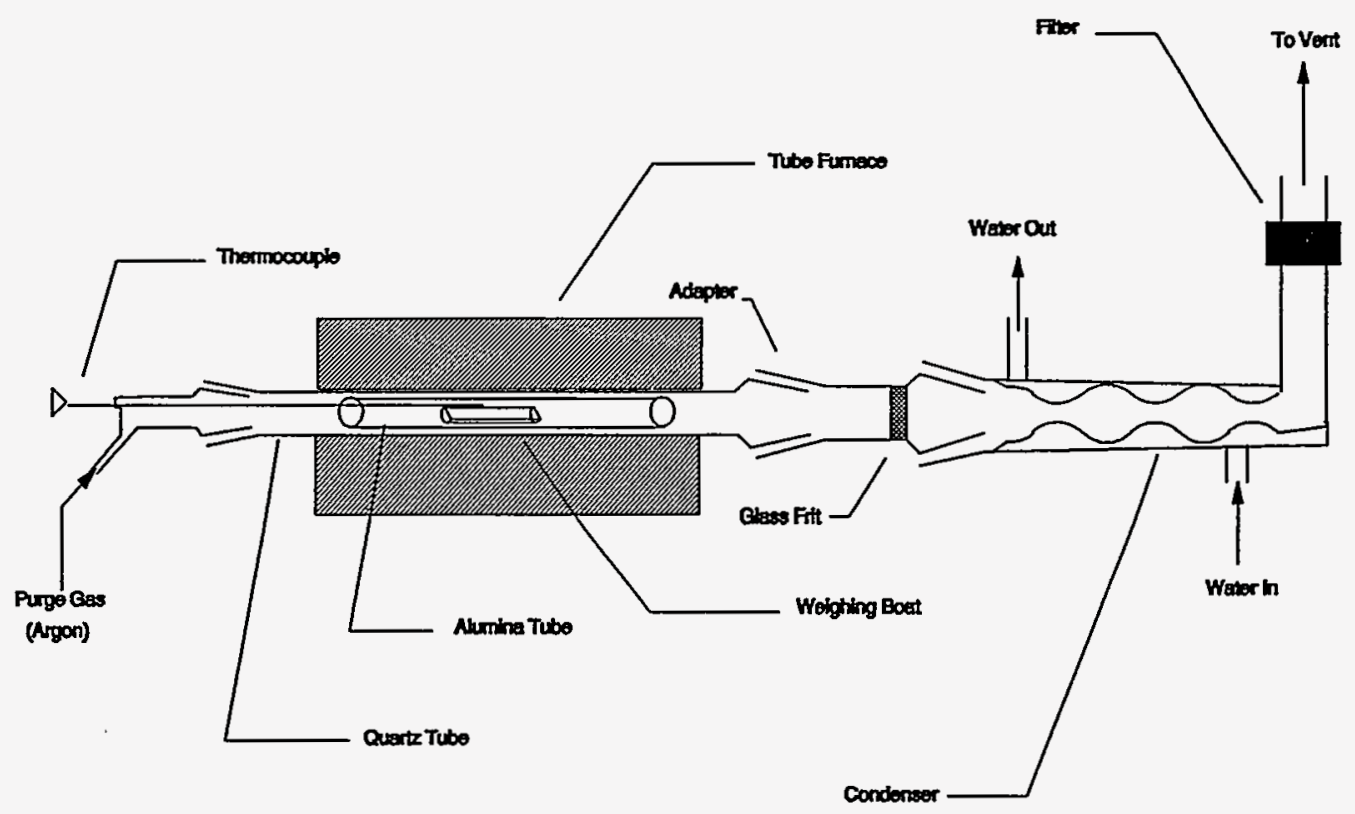

Flgure 1. Cold Calcine Volatiles Test Apparatus for Pilot Plant Caldnes 
Fluorinel/sodium (run LTWM-1-88) calcine was tested at $600-1000^{\circ} \mathrm{C}$ with purge rates in the range of 0.3-4 slpm to determine optimum conditions for cesium volatilization. Run times for these tests were 5 hours. Based on the results of these tests, zirconia (run 74) and alumina (run 77) calcines were tested at 900 and $1000^{\circ} \mathrm{C}$ with a purge rate of $2 \mathrm{slpm}$. For tests conducted at 2 slpm, a quartz wool plug was substituted for the glass frit in the adapter to reduce pressure drops.

\subsection{Hot Tests with NWCF Calcine}

The apparatus used for the hot tests with NWCF calcine is illustrated in Figure 2. A calcine sample was weighed in the platinum crucible, lowered into the alumina tube, and suspended just above the alumina support rod by means of the platinum wire. Sample weights ranged from $1.9500-2.1300$ grams. Purging, drying and degassing operations were similar to those described for the cold tests. The calcine was heated to the test temperature for either 5 or 10 hours. After the alumina tube cooled to near ambient temperatures, and while the system was being purged, the deionized water was drained from the bubbler vessel and collected for analysis. Draining the bubbler vessel while under the argon purge prevented water from entering the bubbler tube, thus enabling determination of the extent of volatiles deposition in the bubbler and bubbler tube separately. The bubbler vessel was then rinsed with $3 \mathrm{~N} \mathrm{HNO}_{3}$ and the rinse collected for analysis The bubbler tube was disconnected from the adapter and rinsed twice with $3 \mathrm{~N} \mathrm{HNO}_{3}$.

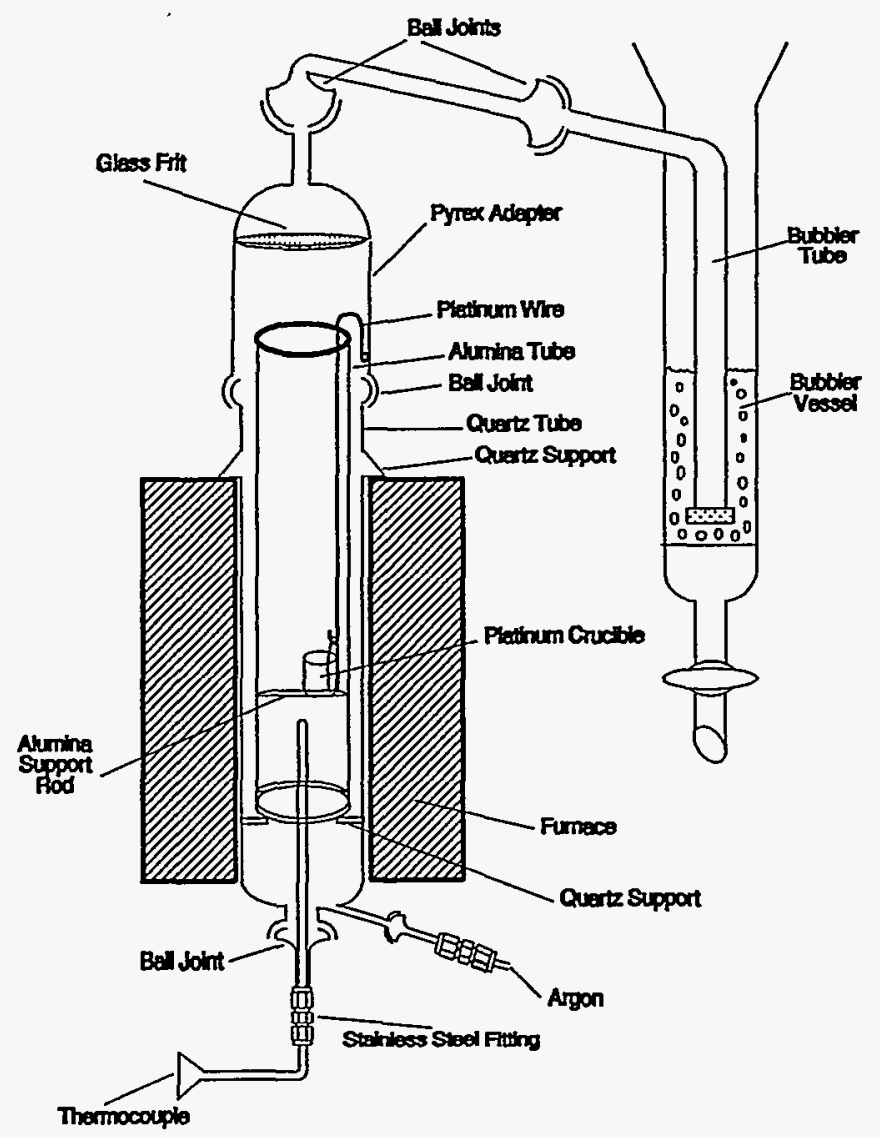

Figure 2 Remote Hot Calcine Volatiles Test Apparatus for NWCF Cakine 
The adapter was then removed and rinsed twice with $3 \mathrm{~N} \mathrm{HNO}_{3}$. The platinum crucible containing the calcine was removed and weighed. The calcine was then removed and the platinum crucible weighed to determine the weight of the calcine after heating. Variations in the weight of the crucible were insignificant.

The alumina tube was removed and the section outside the heated zone was soaked twice in $3 \mathrm{~N}$ $\mathrm{HNO}_{3}$. The solutions were collected for analysis. The platinum wire and crucible were also rinsed and the solutions analyzed. The two rinses of each part of the apparatus were analyzed separately for the first two runs to determine efficiency of deposit removal. However, for the majority of the tests, the two rinses were combined when analyses indicated relatively small amounts in the second rinses.

The heated calcine was analyzed for the components in Table III to determine their volatilities. Calcine samples before and after heating were dissolved by heating in concentrated $\mathrm{HNO}_{3} / \mathrm{HCl}$ mixtures. Based on determination of undissolved solids, calcine dissolution was $96 \%$ and $99 \%$ for two samples heated at $900^{\circ} \mathrm{C}$ and $99 \%$ for two samples heated at $1000^{\circ} \mathrm{C}$. Runs were conducted at $900^{\circ} \mathrm{C}$ for 5 and 10 hours, and at $1000^{\circ} \mathrm{C}$ for 5 and 10 hours. The purge rate was $0.6 \mathrm{slpm}$. Two 5 hour runs at 900 and $1000^{\circ} \mathrm{C}$ with a purge rate of $2 \mathrm{slpm}$ were also conducted. As in the cold tests, the glass frit in the adapter was replaced with quartz wool for tests with the higher purge rate.

\section{DATA ANALYSIS}

Percent volatilization of cesium and cadmium from pilot plant calcines was calculated with equation 1.

$$
\& V=\frac{\left(F_{1} W_{1}-F_{2} W_{2}\right)}{F_{1} W_{1}} \times 100
$$

where,

$$
\begin{aligned}
& \% \mathrm{~V}=\text { percent volatilization } \\
& \mathrm{F}_{1}=\text { weight fraction in calcine before heating } \\
& \mathrm{F}_{2}=\text { weight fraction in calcine after heating } \\
& \mathrm{w}_{1}=\text { calcine weight before heating, } \mathrm{g} \\
& \mathrm{W}_{2}=\text { calcine weight after heating, } \mathrm{g}
\end{aligned}
$$

When only one run was conducted, the error was estimated by propagating the error $(2 \sigma)$ associated with measurements of $F_{1}$ and $F_{2}$ through equation 1 . The propagation of error formula used is equation $2^{5,6}$. 


$$
S v=\frac{100 W_{2} \sqrt{F_{2}^{2}\left(S_{F_{1}}\right)^{2}+F_{1}^{2}\left(S_{F_{2}}\right)^{2}}}{W_{1} \dot{F}_{1}^{2}}
$$

where,

. $\mathrm{Sv}_{1}=$ standard deviation for $\%$ volatilization

$\mathrm{s}_{\mathrm{F}_{1}}=$ standard deviation $(2 \sigma)$ for weight fraction of component before heating.

. $\mathrm{s}_{\mathrm{P}_{2}}=$ standard deviation $(2 \sigma)$ for weight fraction of component after heating.

Percent volatilization of radionuclides from NWCF calcine was calculated with equation 3 .

$$
\& V=\frac{\left(D_{1} w_{1}-D_{2} w_{2}\right)}{D_{1} w_{1}} X 100
$$

where,

$\mathrm{D}_{1}=$ disintegrations/second $(\mathrm{d} / \mathrm{s})$ per gram of calcine before heating

$\mathrm{D}_{2}=$ disintegrations/second $(\mathrm{d} / \mathrm{s})$ per gram of calcine after heating

Standard deviations for $\%$ volatilization were calculated with equation 2 substituting $D_{1}$ and $D_{2}$ for $\mathrm{F}_{1}$ and $\mathrm{F}_{2}$.

Radionuclide decontamination factors $(D F)$ and standard deviations were calculated with equations 4 and 5 respectively.

$$
\begin{gathered}
D F=\frac{D_{1}}{D_{2}} \\
S_{D F}=D F \sqrt{\left(\frac{\left.S_{D_{1}}\right)^{2}+\left(\frac{S_{D_{2}}}{D_{1}}\right)^{2}}{\left(D_{2}\right.}\right.}
\end{gathered}
$$

where $S_{D}$ is the standard deviation $(2 \sigma)$.

The percent of the amount volatilized which was recovered was determined by equation 6 . 


$$
8 R=\frac{T r}{T V} \times 100
$$

where,

$$
\begin{array}{ll}
\% \mathrm{R}= & \text { percent recovered } \\
\mathrm{Tr}= & \text { total mass or } \mathrm{d} / \mathrm{s} \text { in rinse solutions } \\
\mathrm{Tv}= & \text { total mass or } \mathrm{d} / \mathrm{s} \text { volatilized }
\end{array}
$$

\section{RESULTS AND DISCUSSION}

\subsection{Volatilization of Semivolatile Components}

Table IV lists the results of initial scoping tests to determine the effect of temperature on the volatilization of cesium and cadmium from pilot plant calcine. The data indicate that temperatures in excess of $900^{\circ} \mathrm{C}$ are required to remove appreciable amounts of these components. The effect of argon purge rate on cesium and cadmium volatilization from Fluorinel/sodium pilot plant calcine is indicated in Figure 3. A large effect on the diffusion rate of vapor phase species occurred between 0.3 and 2 slpm. The results shown in Table IV and Figure 3 established $1000^{\circ} \mathrm{C}$ and 2 slpm as the conditions resulting in the maximum volatilization rate.

Volatilization data for semivolatile components of four calcine types is summarized in Table V. The data indicate that $>99 \%$ of the cesium can be removed in 5 hours from all the calcines tested by heating to $1000^{\circ} \mathrm{C}$ (for Fluorinel/sodium and alumina calcine) and $1100^{\circ} \mathrm{C}$ (for zirconia and NWCF calcine). Increasing the heating time to 10 hours at $1000^{\circ} \mathrm{C}$ for NWCF calcine resulted in $99 \%$ cesium removal with a purge rate of $0.6 \mathrm{slpm}$.

Table IV

Effect of Temperature on Volatilization of Cesium and Cadmium from Fluorinel/Sodium Pilot Plant Calcine (Run LTWM-1-88)

Temperature, ${ }^{\circ} \mathrm{C}$

600

700

900

1000
$\%$ Volatilized

Cs $\quad \underline{C d}$

ND ND

ND

ND

30

5.6

98

Argon purge rate $=0.3 \mathrm{slpm}$

Run time $=5$ hours

ND $=$ None detected 


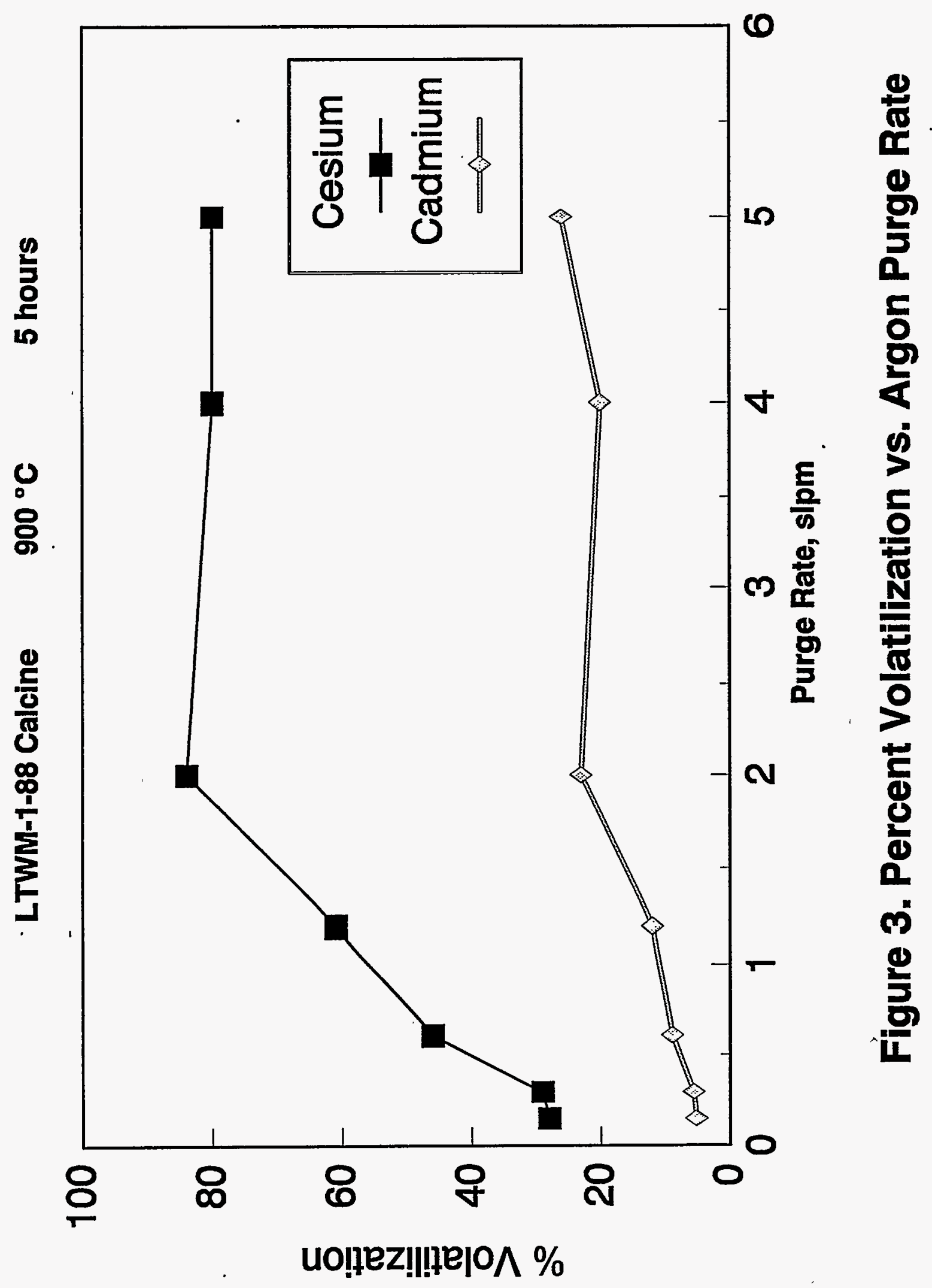


Table V

Percent Volatilization of Semivolatile Components in Four Calcine Types

\begin{tabular}{|c|c|c|c|c|c|c|c|c|c|c|c|c|c|c|c|c|}
\hline \multirow{3}{*}{$\begin{array}{l}\text { Temp, }{ }^{\circ} \mathrm{C} \\
\text { Time, } \mathrm{h}\end{array}$} & \multicolumn{5}{|c|}{$\begin{array}{c}\text { NWCF } \\
\text { 3-way blend* }\end{array}$} & \multicolumn{4}{|c|}{$\begin{array}{l}\text { Fluorinel/Sodium } \\
\text { run LTWM-1-88 }\end{array}$} & \multicolumn{4}{|c|}{$\begin{array}{r}\text { Zirconia } \\
\operatorname{rin} 74 \\
\end{array}$} & \multicolumn{3}{|c|}{$\begin{array}{c}\text { Alumina } \\
\text { nun } 77\end{array}$} \\
\hline & \multicolumn{2}{|c|}{900} & \multicolumn{2}{|c|}{1000} & \multirow[t]{2}{*}{-1170} & \multicolumn{2}{|c|}{900} & \multirow{2}{*}{$\frac{1000}{5}$} & \multirow[t]{2}{*}{1100} & \multicolumn{2}{|c|}{900} & \multirow{2}{*}{$\frac{1000}{5}$} & \multirow[t]{2}{*}{1100} & \multicolumn{2}{|c|}{900} & \multirow{2}{*}{$\frac{1000}{5}$} \\
\hline & 5 & $10^{b}$ & 5 & $10^{6}$ & & 5 & 10 & & & 5 & 10 & & & 5 & 10 & \\
\hline Cs & $47 \pm 5.6$ & $59 \pm 5.4$ & $\begin{array}{l}96 \\
(27 \pm 3.5)^{\circ}\end{array}$ & $\begin{array}{l}99 \\
(94 \pm 10)^{\circ}\end{array}$ & $\begin{array}{l}99.8 \\
(380)^{\circ} \\
99.8 \\
(537)^{\circ}\end{array}$ & $84^{d} \pm 4.2$ & $94 \pm 1.0$ & $\begin{array}{l}99.7 \\
>99 \\
>99\end{array}$ & $\begin{array}{l}>99 \\
>99\end{array}$ & $22 \pm 5.5$ & $41 \pm 4.3$ & $93^{\mathrm{d}} \pm 5.8$ & $\begin{array}{l}>99 \\
>99\end{array}$ & $2.5 \pm 7.0$ & $11 \pm 6.4$ & $\begin{array}{l}99 \\
>99 \\
89\end{array}$ \\
\hline $\mathrm{Cd}$ & $33 \pm 8.3$ & $39 \pm 7.9$ & ND & $65 \pm 4.3$ & 81,86 & $23^{\mathrm{d}} \pm 6.3$ & $27 \pm 7.0$ & $69^{\mathrm{d}} \pm 3.0$ & 82,83 & $11 \pm 6.2$ & $16 \pm 6.1$ & $69^{\mathrm{d}} \pm 3.2$ & 82,83 & c & e & c \\
\hline $\mathrm{Hg}$ & $>94$ & $>94$ & $>94$ & $>94$ & & & & & & & & & & & & \\
\hline${ }^{134} \mathrm{Cs}$ & $57 \pm 7.2$ & $69 \pm 6.0$ & $>99$ & $\begin{array}{l}99 \\
(102 \pm 29)^{\circ}\end{array}$ & & & & & & & & & & & & \\
\hline${ }^{90} \mathrm{Tc}$ & $94 \pm 1.5$ & ND & $94 \pm 1.2$ & $\begin{array}{l}>99 \\
(>528)^{\circ}\end{array}$ & & & & & & & & & & & & \\
\hline
\end{tabular}

a Blend of $\mathrm{Al}, \mathrm{Zr} / \mathrm{Na}$ and $\mathrm{Na}$ wastes processed during campaign $\mathrm{H} 3,3 / 93-10 / 93$.

b Purge rate $=0.6 \mathrm{slpm}$.

c Decontamination Factor.

d Average of 3 runs. Standard deviation is $=2 \sigma$.

- No Cd data due to very small amounts $(0.01 \mathrm{wt} \%)$ present.

NOTES: 1. Results are for one run at stated conditions except where indicated differently.

2. Purge rates $=2$ slpm except where noted.

3. Cesium volatilization data for NWCF calcine based on ${ }^{137} \mathrm{Cs}$ analysis.

4. $\mathrm{ND}=$ No data. 
In terms of decontamination factors, the data indicate that a cesium DF of at least 100 is possible. With the exception of Fluorinel/sodium calcine, cesium volatility was greatly lower at $900^{\circ} \mathrm{C}$ than at $1000^{\circ} \mathrm{C}$ and varied considerably between the four calcine types. Factors to which the variations may be attributed include differences in the cesium chemistries, the formation of different cesium phases during heating, and porosity differences resulting in varying cesium diffusion rates.

Cadmium volatilization at $1000^{\circ} \mathrm{C}$ was not very large for any of the calcines tested. Heating NWCF calcine at $1000^{\circ} \mathrm{C}$ for 10 hours resulted in $65 \%$ of the cadmium being volatilized. Cadmium removal in the $81-86 \%$ range was obtained by heating NWCF, fluorinel/sodium and zirconia calcine at temperatures greater than $1000^{\circ} \mathrm{C}$. However, significant melting of a component of Fluorinel/sodium calcine occurred causing severe agglomeration. The NWCF and zirconia calcines were slightly agglomerated. Mercury volatilization was $>94 \%$ in 5 hours at 900 and $1000^{\circ} \mathrm{C}$.

Volatilization of ${ }^{134} \mathrm{Cs}$ and ${ }^{99} \mathrm{Tc}$ from NWCF calcine was $99 \%$ or greater at $1000^{\circ} \mathrm{C}$. No ${ }^{99} \mathrm{Tc}$ was detected in the calcine after heating as compared with $23 \mu \mathrm{g} / \mathrm{g}$ in the unheated calcine. As expected, volatilization of ${ }^{134} \mathrm{Cs}$ paralleled that of ${ }^{137} \mathrm{Cs}$. No significant volatilization of ${ }^{90} \mathrm{Sr}, \mathrm{Pu}$ or ${ }^{241} \mathrm{Am}$ was detected.

The percent of volatilized $\mathrm{Cs}, \mathrm{Cd}$ and ${ }^{99} \mathrm{Tc}$ that was recovered by dissolving the condensed deposits in $3 \mathrm{~N} \cdot \mathrm{HNO}_{3}$ is listed in Table VI. With the exception of cadmium recovery from NWCF calcine, percent recoveries were high. An analysis of the distribution of condensed deposits outside the heated zone indicated that greater than $96 \%$ of the volatilized components from all tests condensed within $20-\mathrm{cm}$ of the heated zone. The areas of deposition were the quartz tube and adapter of the cold test apparatus (see Figure 1) and the alumina tube and adapter of the hot test apparatus (see figure 2). Temperatures in the quartz and alumina tubes were estimated to be about $200^{\circ} \mathrm{C}$, hence this data suggests the absence of highly volatile vapor phase components. No $\mathrm{Hg}$ was detected in the dissolved condensed deposits. This may have been due to $\mathrm{Hg}$ levels being below detectable limits.

The heated calcines indicated no major structural changes. Fluorinel/sodium and NWCF calcine heated at $1000^{\circ} \mathrm{C}$ for 5 hours resulted in $\mathrm{NaNO}_{3}$ decomposition and partial conversion of $\mathrm{ZrO}_{2}$ to $\mathrm{Ca}_{0.15} \mathrm{Zr}_{0.85} \mathrm{O}_{1.85}$. Calcium fluoride remained a major component of both calcines. Zirconia calcine heated to $1100^{\circ} \mathrm{C}$ for 5 hours retained $\mathrm{CaF}, \mathrm{ZrO}_{2}$ and $\mathrm{Ca}_{0.15}, \mathrm{Zr}_{0.85}, \mathrm{O}_{1.85}$ as the major compounds. Alumina calcine heated to $1000^{\circ} \mathrm{C}$ for 5 hours showed no structural changes. 
Table VI

Percent Recovery of Volatilized Components

\begin{tabular}{|c|c|c|c|c|}
\hline & $\begin{array}{c}\text { NWCF } \\
\text { 3-way blend }^{a}\end{array}$ & $\begin{array}{l}\text { Fluorinel/Sodium } \\
\text { run LTWM-1-88 }\end{array}$ & $\begin{array}{c}\text { Zirconia } \\
\text { run } 74 \\
\end{array}$ & $\begin{array}{c}\text { Alumina } \\
\text { run } 77\end{array}$ \\
\hline Cs & $86^{b} \pm 7$ & $98^{\mathrm{b}} \pm 12$ & $89^{c} \pm 5.6$ & $94^{d}$ \\
\hline $\mathrm{Cd}$ & $58^{b} \pm 6$ & $86^{b} \pm 8$ & $91^{\mathrm{d}}$ & e \\
\hline${ }^{99} \mathrm{Tc}$ & $83^{d}$ & & & \\
\hline
\end{tabular}

a Blend of Aluminum, Zirconium/Na and Sodium wastes processed during campaign H3, 3/93$10 / 93$.

${ }^{b}$ Average of five 5 hour runs at $900-1000^{\circ} \mathrm{C}$. Purge rates ranged from $0.6-2 \mathrm{slpm}$

c Average of 2 runs at $900^{\circ} \mathrm{C}\left(5\right.$ and $10 \mathrm{~h}$ ) and 1 run at $1000^{\circ} \mathrm{C}(5 \mathrm{~h})$. Purge rate $=2 \mathrm{slpm}$

d One run

' No data due to small amounts $(0.01 \mathrm{wt} \%)$ of $\mathrm{Cd}$ present.

\subsection{Characterization of Condensed Semivolatiles}

Condensation of volatilized components of Fluorinel/sodium, zirconia and alumina calcines outside the heated zone was first visible at a calcine temperature of $900^{\circ} \mathrm{C}$ and appeared as a white deposit. As the temperature was increased to $1000^{\circ} \mathrm{C}$, the white deposit became heavier, and in the case of cadmium-containing calcines ( $\mathrm{F} 1 / \mathrm{Na}$ and zirconia), deposition of a black and brown substance identified as $\mathrm{CdO}$ occurred. In addition to $\mathrm{CdO}$, heating Fluorinel/sodium calcine which contains a large amount of cadmium $(4.9 \mathrm{wt} \%)$ above $900^{\circ} \mathrm{C}$ resulted in deposition of cadmium metal. Cadmium in the zirconia calcine tested is a contaminant and may not be present in actual zirconia calcine.

The only visible deposit due to heating NWCF calcine at $1000^{\circ} \mathrm{C}$ was a black powder. Analysis by emission spectrometry determined that the only metal present was cadmium. X-ray diffraction analysis indicated that the compound was amorphous. This compound was presumed to be amorphous CdO.

Figures 4 and 5 are photographs of condensed semivolatiles from heating alumina and zirconia calcine at $1000^{\circ} \mathrm{C}$ for 20 hours. Elemental and X-ray diffraction analyses of the deposits are listed in tables VII and VIII respectively. The elemental analysis indicated that on a mole \% basis, fluoride and sulfur (as $\mathrm{SO}_{4}^{=}$) were the major nonmetals present. Thus, in addition to $\mathrm{Cs}_{2} \mathrm{SO}_{4}$, cesium condensed in combination with fluoride as an amorphous compound or compounds. This material is shown as the white deposit in Figures 4 and 5. Sodium was a major component of the condensed deposits that resulted from heating alumina calcine, and may have condensed as an amorphous fluoride. 


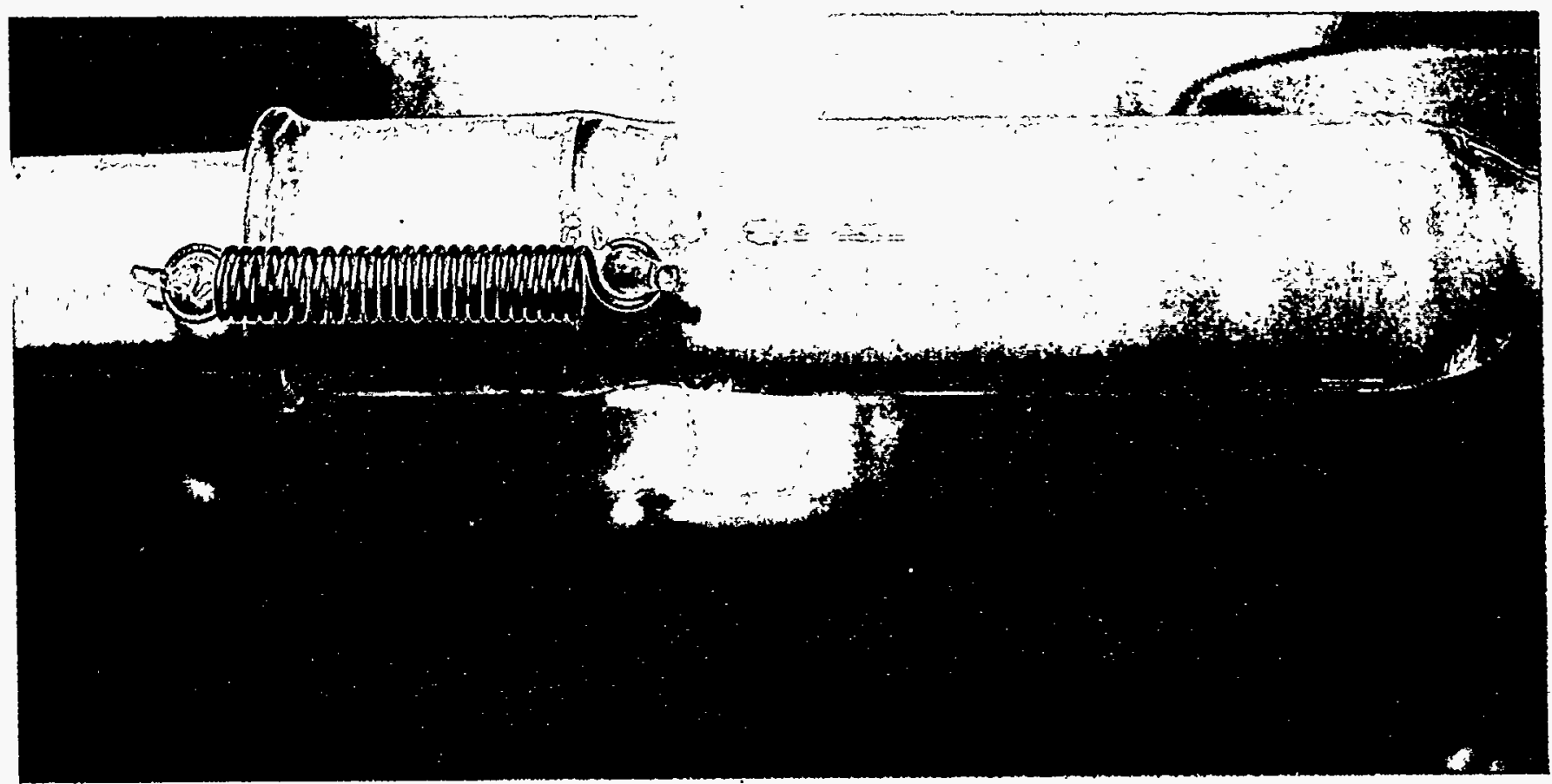

Figure 4. Condensed Semivolatiles from Heating Alumina Calcine at $1000^{\circ} \mathrm{C}$ for 20 Hours.

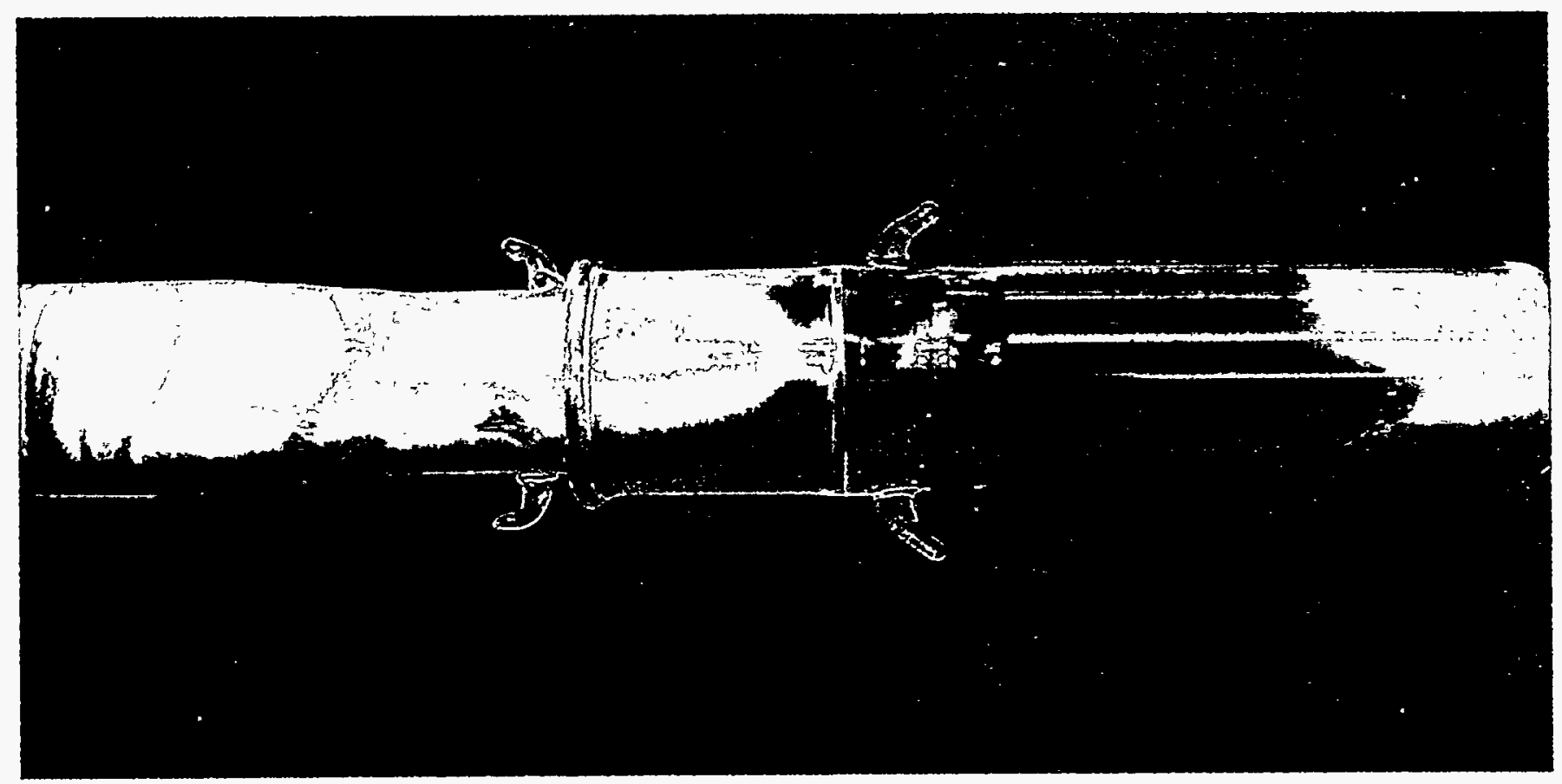

Figure 5. Condensed Semivolatiles from Heating Zirconia Calcine at $1000^{\circ} \mathrm{C}$ for 20 Hours. 
The cesium component of the condensed volatiles was completely soluble in deionized water. Thus, in a full scale process, separation of cesium for further processing may be feasible by ion exchange methods. Condensed $\mathrm{S}$ and $\mathrm{CdO}$ was not soluble in deionized water but completely dissolved in $3 \mathrm{~N} \mathrm{HNO}_{3}$. The treatment of a cadmium waste stream will have to be considered especially when processing Fluorinel/Na calcine.

Table VII

Elemental Analysis of Condensed Semivolatiles

\begin{tabular}{|c|c|c|c|c|}
\hline & \multicolumn{2}{|c|}{ Alumina Calcine } & \multicolumn{2}{|c|}{$\underline{\text { Zirconia Calcine }}^{\mathrm{a}}$} \\
\hline & $\mathrm{Wt} \%$ & Mole \% & $\mathrm{Wt} \%$ & Mole \% \\
\hline Cs & 50 & 15 & 50 & 25 \\
\hline $\mathrm{Na}$ & 12 & 19 & 0.72 & 2.0 \\
\hline B & 1.8 & 6.4 & 1.1 & 6.5 \\
\hline $\mathrm{Al}$ & 1.1 & 1.5 & 0.57 & 1.3 \\
\hline $\mathrm{Cd}$ & 0.82 & 0.30 & 17 & 9.7 \\
\hline F & 26 & 54 & 12 & 42 \\
\hline $\mathrm{SO}_{4}^{-}$ & 7.9 & 3.1 & 17 & 11 \\
\hline $\mathrm{Cl}$ & 0.74 & 0.80 & 1.7 & 3.1 \\
\hline $\mathrm{NO}_{3}^{-}$ & 0.2 & 0.14 & 0.29 & 0.30 \\
\hline Totals & 100.6 & 100.2 & 100.4 & 100.9 \\
\hline
\end{tabular}

${ }^{a}$ White deposit shown in Figure 5.

Table VIII

$\mathrm{X}$-ray Diffraction Analysis of Condensed Semivolatiles

Alumina Calcine

$\mathrm{Cs}_{2} \mathrm{SO}_{4}$

Amorphous

Material
Zirconia Calcine

Yellow Deposit - Sulfur

White Deposit - $\mathrm{Cs}_{2} \mathrm{SO}_{4}$

- Amorphous

- Material

Brown Deposit - CdO 


\section{CONCLUSIONS}

1. Removal efficiencies for ${ }^{137} \mathrm{Cs}$ and ${ }^{99} \mathrm{Tc}$ of $99 \%(\mathrm{DF}=100)$ should be possible by heating Fluorinel/sodium, alumina and NWCF calcine to $1000^{\circ} \mathrm{C}$ for 5-10 hours. Removal of $99 \%$ of the cesium from zirconia calcine requires heating to $1100^{\circ} \mathrm{C}$. A decontamination factor of 100 for ${ }^{137} \mathrm{Cs}$ is sufficient to allow designation of high-level waste calcine as a Class B waste with respect to ${ }^{137} \mathrm{Cs}$. A Class A designation requires a DF of 4200 which tests indicate is not possible by heating calcine at $1000^{\circ} \mathrm{C}$.

2. High cadmium removal efficiencies ( $>90 \%$ ) are not possible by heating calcine at $1100^{\circ} \mathrm{C}$. Heating Fluorinel/ $\mathrm{Na}$ calcine at this temperature results in melting, which causes severe agglomeration.

3. Removal of condensed ${ }^{137} \mathrm{Cs},{ }^{99} \mathrm{Tc}$ and $\mathrm{Cd}$ compounds for further processing can be accomplished by dissolution in $3 \mathrm{~N} \mathrm{HNO}_{3}$. Condensed cesium compounds can be removed by dissolution in deionized water. This should facilitate separation by ion exchange methods such as using zeolites which can be incorporated into a high-level waste glass.

4. Heat treatment of Fluorinel/sodium calcine at $1000^{\circ} \mathrm{C}$ should not result in significant agglomeration particularly if a fluidized bed or rotary kiln is used. These methods should result in increased diffusion rates for semivolatiles and therefore maximize removal efficiencies. Zirconia and alumina calcines can be heated to $1100^{\circ} \mathrm{C}$ without significant agglomeration or major structural changes. 


\section{REFERENCES}

1. G. W. Wilds, Vaporization of Semivolatile Components from Savannah River Plant Waste Glass, DP-1504 (August 1978).

2. A. E. Albrethson and L. C. Schwendiman, Volatilization of Fission Products from HighLevel Ceramic Wastes, BNWL-338 (February 1967).

3. P. W. Cains, K. C. Vewer and S. Waring, "Volatilization of Ruthenium, Cesium and Technetium from Nitrate Systems in Nuclear Fuel Processing and Waste Solidification," Radiochimica Acta 56, pp. 99-104 (1992).

4. C. W. Sill, "Volatility of Cesium and Strontium from a Synthetic Basalt", Nuclear and Chemical Waste Management, Vol. 8, pp. 97-105 (1988).

5. S. L. Meyer, Data Analysis for Scientists and Engineers, John Wiley, 1975.

6. J. M. Mines and I. R. Thomas, WINCO, personal communications. 